\title{
GAMBARAN STATUS GIZI TERHADAP KEJADIAN TB PARU DI RUMAH SAKIT IMELDA MEDAN TAHUN 2018
}

\author{
1. Sarmaida Siregar; ${ }^{2}$ Vita Sari Tampubolon \\ 1. Dosen Prodi D-III Keperawatan STIKes Imelda, Jalan Bilal Nomor 52 Meda \\ ;2.Alumni STIkesSImelda \\ E-mail: ${ }^{1 .}$ Sarmaidabahtiar.123@gmail.com
}

\begin{abstract}
ABSTRAK
Tuberkulosis adalah penyakit menular langsung yang disebabkan oleh kuman TBC (Mycobacterium tuberculosis). Salah satu faktor yang mempengaruhi terjangkitnya penyakit tuberkulosis paru adalah status gizi. Status gizi yang yang buruk akan meningkatkan risiko penyakit tuberkulosis paru. Sebaliknya, tuberkulosis paru berkontribusi menyebabkan status gizi buruk karena proses perjalanan penyakit yang mempengaruhi daya tahan tubuh. Hal ini yang menjadi salah satu alasan utama peneliti untuk mengetahui gambaran status gizi terhadap kejadian TB Paru di Rumah Sakit Umum Imelda Pekerja Indonesia Medan. Jenis penelitian adalah deskriptif yang dilaksanakan di Rumah Sakit Imelda dan bertujuan untuk mengetahui gambaran Status Gizi terjadap kejadian TBParu di Rumah Sakit Imelda Medan. Pengambilan sampel menggunakan teknik non probability sampling jenis purposive sampling yang memenuhi kriteria inklusi sebanyak 45 orang. Hasil penelitian menunjukan status 5 gizi pada pnderita TB Paru dengan kriteria kurang tingkat berat sebanyak 17 responden (37,78\%), dengan kriteria kurang tingkat ringan sebanyak 9 responden (20\%), dengan kriteria normal sebanyak 19 responden (42,22\%), sedangkan tidak ditemukan responden dengan kriteria lebih tingkat ringan.

Hasil dari penelitian ini diharapkan kepada perawat di Rumah sakit Imelda Medan untuk melakukan upaya penyuluhan atau pemberian informasi mengenai cara pencegahan, penularan, tanda, gejala tuberkulosis paru, dan hal-hal yang dapat menghambat penyembuhannya seperti merokok baik kepada penderita maupun kepada orang-orang yang berada di sekitar penderita sehingga penularannya dapat dicegah.
\end{abstract}

Kata Kunci: Status gizi, Penyakit TB Paru

\section{PENDAHULUAN}

Tuberkulosis adalah penyakit menular langsung yang disebabkan oleh kuman TBC (Mycobacterium tuberculosis) (Kemenkes RI, 2013). Tuberkulosis merupakan infeksi bakteri kronik yang disebabkan oleh Mycobacterium tuberculosis dan ditandai oleh pembentukan granuloma pada jaringan yang terinfeksi dan oleh hipersensifitas yang diperantarai sel (cellmediated hypersensitivity) (Wahid dan Suprapto, 2014).

Menurut Mahdiana (2010) infeksi tuberkulosis masih menjadi masalah kesehatan bagi masyarakat Indonesia dengan lokasi infeksi primernya pada organ paru, namun tidak selamanya organ tubuh yang diserang oleh basil tuberkel ini adalah paruparu, tetapi dapat pula terjadi pada sendi atau tulang, ginjal, usus, rahim, dan getah bening (leher) yang dapat berdampak pada kematian (mortalitas). Terjangkitnya infeksi tuberkulosis ini ditandai dengan hasil pemeriksaan sputum Basil Tahan Asam (BTA) positif dengan mengumpulkan tiga spesimen dahak yaitu Sewaktu-PagiSewaktu (SPS) dan foto toraks. Selain itu pemeriksaan sputum juga bertujuan untuk menentukan tingkat penularan infeksinya (Ben-Salma, dkk., 2009).

Menurut laporan global tuberkulosis WHO ( World Health Organitation ), tahun 2015 diperkirakan ada 9,6 juta kasus baru TB di dunia dan 1,5 juta orang meninggal karena TB pada tahun 2014. Asia Tenggara dan Pasifik Barat menyumbang 58\% dari kasus TB di dunia pada tahun 2014. Prevalensi TB di Indonesia dan negara negara berkembang lainnya cukup tinggi. Indonesia menempati posisi tiga besar negara dengan jumlah kasus tuberkulosis 
terbanyak bersama India dan Cina. Berdasarkan profil data kesehatan Indonesia terkait TBC,sesuai data WHO Global Tuberkulosis report 2016, Indonesia menempati posisi kedua dengan beban tertinggi di dunia. Jumlah kasus baru TB paru BTA positif di seluruh provinsi di Indonesia sebanyak 176.677 kasus. Menurut profil Kesehatan Kemenkes RI tahun 2016 , Jawa Barat adalah provinsi dengan jumlah total kasus TBC terbanyak pada tahun 2016, yaitu 52.328 orang dengan rincian 29.429 laki-laki dan 22.899 perempuan. Kemudian disusul oleh Jawa Timur (45.239), Jawa Tengah (28.842). Sedangkan di Provinsi Sumatra Utara sebanyak 156.408 kasus.

Sedangkan menurut jenis kelamin, tertinggi terjadi pada laki-laki sebanyak 2.308 kasus dan perempuan hanya 1.256 kasus. Menurut profile kesehatan Provinsi Sumatra Utara pada tahun 2016,CNR ( Cross Notification Rate) (kasus baru) TB Paru BTA (+) di sumatra utara mencapai 105,02/ 100.000 penduduk. Pencapain Kab/Kota,3(tiga) tertinggi adalah kota medan sebesar 3.006/100.000, Kab.Deli serdang sebesar 2.184/100.000 dan Simalungun sebesar 962/100.000). sedand 3(3) Kab/Kota terendah adalah Kab.Nias Barat 50/100.000, Pakpak Barat sebesar $67 / 100.000$ dan Gunung Sitoli sebesar 68/100.000 .

Berdasarkan data rekam medik Rumah Sakit Umum Imelda Pekerja Indonesia Medan (RSU IPI) Medan, pada tahun 2017 penderita TB Paru sebesar 120 Orang sedangkan pada tahun 2018, yaitu dari bulan Januari- Mei sebesar 76 Orang .

Salah satu faktor yang mempengaruhi terjangkitnya penyakit tuberkulosis paru adalah status gizi. Status gizi adalah cerminan ukuran terpenuhi kebutuhan gizi. Status gizi secara parsial dapat di ukur dengan antopometri (pengukuran bagian tertentu dari tubuh) atau biokimia atau secara klins (Sandjaya,2009). Selain itu status gizi dapat diartikan sebagai ekspresi dari keadaan keseimbangan dalam bentuk variabel tertentu, atau perwujudan dari nutriture dalam bentuk variabel tertentu (Supraisa,2013).
Faktor yang Mempengaruhi Status Gizi remaja menurut Dewi dkk (2013) yaitu :Faktor Keturunan, Faktor Gaya Hidup, Faktor Lingkungan seperti kebiasaan minum-minuman beralkhol dapat menimbulkan gangguan pada hati (hepamotologi bahkan sirosis), kebiasaan merokok dapat menimbulkan ISPA kronis bahkan TB paru atau kanker paru, kebiasan begadang tiap malam dapat menyebabkan daya tahan tubuh menjadi menurun sehingga mudah terserang infeksi.

Pasien TB paru seringkali mengalami penurunan status gizi, bahkan dapat menjadi malnutrisi bila tidak diimbangi dengan diet yang tepat. Beberapa faktor yang berhubungan dengan status gizi pada pasien TB paru adalah tingkat kecukupan energi dan protein, perilaku pasien terhadap makanan dan kesehatan, lama menderita TB paru, serta pendapatan perkapita pasien. Infeksi TB mengakibatkan penurunan asupan dan malabsorpsi nutrien serta perubahan metabolisme tubuh sehingga terjadi proses penurunan massa otot dan lemak (wasting) sebagai manifestasi malnutrisi energi protein.

Hubungan antara infeksi TB dengan status gizi sangat erat, terbukti pada suatu penelitian yang menunjukkan bahwa infeksi TB menyebabkan peningkatan penggunaan energi saat istirahat resting energy expenditure (REE). Peningkatan ini mencapai $1030 \%$ dari kebutuhan normal.(Elsa Puspita, 2016).

Berdasarkan latar belakang diatas penulis tertarik untuk meneliti tentang : "Gambaran Status Gizi terhadap kejadian TB Paru di Rumah Sakit Umum Imelda Pekerja Indonesia (RSU IPI) Medan”.

\section{Perumusan Masalah}

Berdasarkan latar belakang yang telah dikemukakan, maka yang menjadi rumusan masalah dalam penelitian ini adalah bagaimana Gambaran Status Gizi terhadap kejadian TB Paru di Rumah Sakit Umum Imelda Pekerja Indonesia (RSU IPI) Medan. 


\section{Tujuan Penelitian}

Mendeskripsikan Status Gizi terhadap kejadian TB Paru di Rumah Sakit Umum Imelda Pekerja Indonesia (RSU IPI) Medan.

\section{Manfaat Penelitian}

Pelayanan Kesehatan Rumah Sakit Umum Imelda Pekerja Indonesia (RSU IPI) Meningkatkan wawasan perawat tentang status gizi terhadap terhadap kejadian TB Paru.

1. Bagi Institusi Pendidikan Keperawatan Diharapkan dapat menambah khasanah pengetahuan kepada Stikes Imelda Gambaran Status Gizi terhadap kejadian TB Paru di Rumah Sakit Umum Imelda Pekerja Indonesia (RSU IPI) Medan.

2. Bagi Peneliti Selanjutnya

Diharapkan dapat menjadi tambahan referensi tentang status gizi terhadap kejadian TB Paru. Pelayanan kesehatan.

\section{METODE}

\section{Jenis Penelitian}

Metode penelitian deskriptif adalah suatu metode penelitian yang dilakukan dengan tujuan untuk membuat gambaran atau deskriptif tentang suatu keadaan secara objektif

\section{Waktu Penelitian}

Penelitian dilakukan pada bulan Februari sampai Juli 2018.

\section{Tempat Penelitian}

Medan

Penelitan dilakukan di RSU Imelda

\section{Populasi}

Populasi pada penelitian ini adalah seluruh pasien yang dirawat di Rumah Sakit Umum Imelda berjumlah 76 orang

\section{Sampel dan Teknik Sampling}

Dengan menggunakan rumus sloven maka sampel diperoleh sebanyak 45 orang.

\section{Instrumen Penelitian}

Instrumen penelitian yang digunakan dalam penelitian ini yaitu dengan menggunakan kuesioner.

\section{Sumber Data}

Adapun sumber data yang digunakan yaitu:

1. Data primer

Data yang diperoleh sendiri oleh peneliti dari hasil pengukuran, pengamatan, survey, dan lain-lain.

2. Data Sekunder

Data yang diperoleh sendiri oleh peneliti dari hasil pengukuran, pengamatan, survey dan lain-lain.

Data yang diperoleh sendir

3. Data sekunder

Data yang diperoleh dari pihak lain, badan/instansi yang secara rutin mengumpulkan data.

\section{HASIL}

Tabel 1. Distribusi Frekuensi Identitas Responden Berdasarkan Umur , Jenis kelamin, Tingkat pendidikan pasien terhadap kejadian TB Paru $(n=45)$

\begin{tabular}{cccc}
\hline No & $\begin{array}{c}\text { Data } \\
\text { Demografi }\end{array}$ & $\mathbf{f}$ & Persentase \\
\hline 1 & $-<40$ tahun & 14 & $31,1 \%$ \\
& & & \\
\hline 2 & $-40-49$ & 9 & $20,0 \%$ \\
3 & $->50$ tahun & 22 & $48,9 \%$ \\
& Total & $\mathbf{4 5}$ & $\mathbf{1 0 0 \%}$ \\
\hline \multicolumn{5}{c}{ Pendidikan } & $\mathbf{f}$ & Persentase \\
& terakhir \\
\hline 1 & SMP & 10 & 22,2 \\
2 & SMA & 30 & 66,7 \\
3 & D-III & 5 & 11,1 \\
\hline \multicolumn{5}{c}{ Total } & $\mathbf{4 5}$ & $\mathbf{1 0 0}$ \\
\hline No & Jenis & $\mathbf{f}$ & Persentase \\
\hline \multicolumn{5}{c}{ Kelamin } \\
\hline 1 & Perempuan & 15 & 60.0 \\
\hline 2 & Laki-laki & 30 & 40,0 \\
\hline \multicolumn{5}{c}{ Total } & $\mathbf{4 5}$ & $\mathbf{1 0 0}$ \\
\hline
\end{tabular}

Tabel 2.Distribusi Status Gizi pada penderita Tuberkulosis di Rumah Sakit Imelda

\begin{tabular}{ccccc}
\hline No & Status Gizi & n & \multicolumn{2}{c}{$\%$} \\
\hline 1 & $\begin{array}{l}\text { Kurang tingkat } \\
\text { berat }\end{array}$ & 17 & 37,78 & $\%$ \\
2 & $\begin{array}{l}\text { Kurang tingkat } \\
\text { ringan }\end{array}$ & 9 & 20 & $\%$ \\
3 & $\begin{array}{l}\text { Normal } \\
\text { Lebih tingkat } \\
\text { ringan }\end{array}$ & 19 & 42,22 & $\%$ \\
\hline \multicolumn{1}{c}{ Jumlah } & 45 & 100 & $\%$ \\
\hline
\end{tabular}


Berdasarkan tabel di atas, dapat dilihat bahwa status gizi responden sebagian besar termasuk kategori normal sebesar 19 Orang walaupun masih banyak juga responden yang berstatus gizi kurang tingkat berat sebesar 17 Orang.

Tabel 3. Distribusi Status Gizi berdasarkan pengetahuan tentang Tuberkulosis di Rumah Sakit Imelda

\begin{tabular}{|c|c|c|}
\hline $\begin{array}{c}\text { Kriteria Pengetahuan } \\
\text { TB Paru }\end{array}$ & $\begin{array}{l}\text { Jumlah } \\
\text { (orang) }\end{array}$ & $\begin{array}{c}\text { Persenta } \\
\text { se }(\%)\end{array}$ \\
\hline Baik & 10 Orang & $22,2 \%$ \\
\hline Cukup & 33 Orang & $73,34 \%$ \\
\hline Kurang & 2 Orang & $4,44 \%$ \\
\hline Total & 45 Orang & 100 \\
\hline
\end{tabular}

Berdasarkan tabel di atas, dapat dilihat bahwa distribusi status gizi responden berdasarkan pengetahuan tentang tuberkulosi mayoritas responden berpengetahuan baik 33 orang $(73,34 \%)$ dan minoritas berpengetahuan kurang berjumlah 2 orang $(4,44 \%)$

\section{PEMBAHASAN}

Berdasarkan hasil penelitian tentang Gambaran Status Gizi Terhadap Kejadian TB Paru di Rumah Sakit Umum Imelda Pekerja Indonesia (RSU IPI) Medan Tahun 2018 dengan jumlah sampel 45 Orang yang TB Paru dapat dijelaskan sebagai berikut :

\section{Berdasarkan Pengetahuan}

Berdasarkan hasil penelitian diketahui bahwa 45 Orang yang menderita TB Paru mempunyai pengetahuan tentang TB Paru pada Usia yang berbeda di Rumah Sakit Umum Imelda Pekerja Indonesia (RSU IPI) Medan Tahun 2018, mayoritas responden berpengetahuan baik sebanyak $(73,34 \%)$ dan minoritas berpengetahuan cukup sebanyak $(22,22 \%)$.

Pengetahuan merupakan hasil dari "tahu" dan ini terjadi setelah orang melakukan penginderaan terhadap suatu objek tertentu. Penginderaan terjadi melalui panca indra manusia, yaitu indra penglihatan, pendengaran, penciuman, rasa dan raba, sebagian besar pengetahuan manusia di peroleh melalui mata dan telinga. (Notoatmodjo, 2007).
Menurut asumsi peneliti, dari hasil penelitian yang telah di lakukan terlihat bahwa tingkat pengetahuan 45 Orang yang menderita TB Paru mayoritas berpengetahuan baik. Hal ini dikarenakan responden TB Paru mayoritas tamamatan SMA, sehingga lebih besar peluang responden untuk mengetahui tentang TB Paru melelui media cetak.

\section{Berdasarkan Umur}

Berdasarkan hasil penelitian Tingkat Pengetahuan responden Tentang Status Gizi terhadap kejadian TB Paru di Rumah Sakit Umum Imelda Pekerja Indonesia (RSU IPI) Medan Tahun 2018. Menunjukkan responden mayoritas Umur >50 Tahun (48,9\%), sedangkan minoritas Umur 40- 49 Tahun $(20 \%)$.

Umur adalah lamanya hidup yang dihitung sejak lahir, umur merupakan periodeterhadap kehidupan yang baru. Semakin bertambah umur seseorang maka semakin banyak pula pengetahuan yang di miliki.

Peneliti beramsumsi bahwa dengan umur dapat mempengaruhi pengetahuan seseorang semakin bertambahnya umur seseorang maka semakin banyak pula pengalaman dan semakin banyak orang membaca semakin tinggi pula pengetahuan.

Berdasarkan hasil penelitian menunjukkan bahwa pengetahuan Responden tentang Status Gizi Terhadap Kejadian TB Paru, mayoritas responden berpendidikan SMA sebanyak $(66,7 \%)$ dan minoritas respnden berpendidikan D-III sebanyak 5 orang $(11,1 \%)$.

\section{Berdasarkan Pendidikan}

Pendidikan pada hakikatnya adalah suatu proses pengubahan sikap atau tingkah laku seseorang atau kelomok, juda usaha untuk mendewasakan mnusia melalui upaya pengajaran dan di mana semakin tingginya pendidikan manusia maka akan semakin berkualitas dan mudah dalam penafsiran dan mengaplikasikan sesuai dengan panca indera. 


\section{KESIMPULAN}

Berdasarkan hasil penelitian yang telah dilakukan, maka diperoleh kesimpulan sebagai berikut:

1. Penderita Tuberkulosis paru dirumah sa kit Imelda mayoritas kategori normal sebesar $42,22 \%$ dan minoritas berstatus gizi kurang tingkat ringan sebesar $20 \%$.

2. Pengetahuan penderita tuberculosis paru mengenai penyakitnya mayoritas berpengetahuan cukup $(73,4 \%)$ dan minorita berpengetahuan kurang sebesar $(4,44 \%)$.

\section{SARAN}

1. Diharapkan bagi pemegang program tuberculosis paru di Rumah Sakit Imelda untuk melakukan upaya penyulu han atau pemberian informasi mengenai cara pencegahan, penularan, tanda dan gejala tuberculosis dan hal hal yang dapat menghambat penye mbuhannya

2. Bagi penderita tuberkulosis di Rumah Sakit Imelda Medan diharapkan untuk memperhatikan makanan yang dikonsumsi, terutama makanan sumber protein tinggi

\section{DAFTAR PUSTAKA}

Achmadi.(2008). Journal Tuberculosis and Nutrition. 2009: vol 26 (1).

Damayani. (2013). Buku Pintar Panduan Bimbingan KONSELING. Yogyakartaa : Araska.
Elsa Puspita. (2016). Prinsip dasar Ilmu Gizi. Gramedia Pustaka Utama: Jakarta.

Hamdi.(2014). Metode Penelitian Kuantitatif Aplikasi dalam penelitian. Yogyakarta: Deepublisher.

Hastono, Sutanto. (2007). Analisa Data Kesehatan. Jakarta: Universitas Indonesia.

Irianto. (2014). Pengantar Pangan dan Gizi, Jakarta: Penebar Swadaya.

Losief et al. (2008). Global Tuberculosis. Report 2007. Geneva, Switzerland.

Mahdiana. (2010). Mengenal, mencegah dan mengobati penularan penyakit dari infeksi. Yogyakarta: Citra Pustaka.

Notoatmodjo, S., 2007. Domain Perilaku. Dalam : Promosi Kesehatan dan Dalam: Pendidikan dan Perilaku Kesehatan. Jakarta: Rineka Cipta.

Notoatmodjo, Soekidjo, 2012. Konsep Perilaku dan Perilaku Kesehatan.

Riduwan. 2013. Skala Pengukuran VariabelVariabel Penelitian. Bandung: Alfabeta.

Ruslianti. (2013). Gizi Terapan. Bandung: PT Remaja Rosdakarya

Sandjaya. (2009). PEngantar Ilmu Gizi. Banding: ALFABETA.

Saryono.(2009). Metodologi Penelitian Kesehatan penuntun praktis pemula. Jogjakarta: Mitra Cendikia Pres.

Setiadi. (2008). Konsep dan Penulisan Riset Keperawatan. Yogyakarta: Graha Ilmu.

Varney. (2008). Status Nutrisi berperan dalam kejadian tuberculosis. Yogyakarya: Mitra Medika Pres. 